\title{
Effects of flooding and its temporal variation on seedling recruitment from the soil seed bank of a Neotropical floodplain
}

\section{Evaldo Benedito de Souza ${ }^{1 *}$, Fernando Alves Ferreira' and Arnildo Pott ${ }^{1}$}

Received: June 12, 2016

Accepted: September 27, 2016

\begin{abstract}
Evaluation of the effects of flooding on seedling recruitment from seed banks helps in understanding vegetation regeneration in floodplains. We studied the effects of simulated flooding on richness and abundance of, and temporal variation in, seedling recruitment from the soil seed bank of a floodable savanna of the Pantanal wetland, under two conditions: 1) Post-flood = inundated for 30 days followed by irrigation; 2) Non-flooded = only irrigated. We recorded emerged seedlings biweekly for 120 days and found a total of 124 species for the two treatments, the most abundant species were annual herbs (e.g., Richardia grandiflora and Euploca procumbens) and annual graminoids (e.g., Digitaria ciliaris and Cyperus haspan). Flooding positively influenced seedling richness and abundance, while seedling emergence from the non-flooded soil was slower, but continued during all periods. The different temporal patterns between treatments showed that flooding increases the abundance of emerged seedlings and acts as a trigger for explosive recruitment shortly after water depletion.
\end{abstract}

Keywords: Pantanal, plant ecology, savanna regeneration, seedling abundance, wetland

\section{Introduction}

Flooding causes seasonal changes in the structure and floristic composition of floodplain vegetation (Junk et al. 1989; Cunha \& Junk 2001; Middleton 2002). Cycles of flood and drought, (i.e., the temporal and spatial variation in water level) influence the availability of habitats with the conditions necessary for seedling establishment, thereby allowing the occurrence of species with different life-strategies for the various phases of the hydrological cycle (Valk 2005). Changes caused by annual and recurrent flooding can result in plant adaptations that can increase species diversity; therefore, a high level of biodiversity adapted to different conditions can be expected in floodplains (Alho \& Sabino 2012; Pott \& Silva 2015). Therefore, annual and perennial species can be expected in such environments, either as adults, juveniles, seeds or as other viable propagules, thereby maintaining diversity (Valk 1981). Thus, flooding selects species that are able to colonize floodplains, and so is considered the most important environmental filter in such environments (Valk 1981; Junk et al. 1989).

On the other hand, there are many species that are adapted to highly seasonal habitats, and so produce a transitory seed bank that disperse seeds during seasons for germination (Valk \& Davis 1978; Leck 1989). Floods

\footnotetext{
${ }^{1}$ Programa de Pós-Graduação em Biologia Vegetal, Universidade Federal de Mato Grosso do Sul, Cidade Universitária s/n, 79070-900, Campo Grande, Mato Grosso do Sul, Brazil

*Corresponding author: bs.evaldo@gmail.com
} 
can favor annual and perennial herbs as well as graminoid species, the most common life forms in the seed bank of floodplains (Pagotto et al. 2011; Bao et al. 2014). Many of wetland species, generally annuals, produce persistent seed banks with a large number of seeds with high longevity (Middleton 2003). The long persistence of these seeds in the soil is essential for the maintenance of the biodiversity of these communities during extreme events, such as prolonged droughts, by remaining viable in the seed bank until adequate conditions for germination return (Bossuyt \& Honnay 2008).

In this sense, flooding is necessary for regenerating floodplain vegetation since many annual plants (graminoids and herbs) tend to subsequently emerge from the seed bank with more abundance than perennials (Capon 2007). However, some annual species have a strong response in flood free soil, even though they may have been waterlogged for several weeks (Capon 2007). Herbaceous species usually have fast growth and abundant seed production (Baldwin \& Derico 1999), which is an advantage over woody plants early in succession, which generally have a slower start due to flood intolerance, and colonizing more elevated areas where flooding is shorter and less intense (Pott \& Silva 2015).

The length of dry and flooded conditions is known to affect seed germination both positively and negatively (Brock 2011). Increased flood levels tend to significantly reduce seedling emergence (Peterson \& Baldwin 2004); however, floodings of all magnitudes can result in considerable germination from the soil seed bank (Capon 2007). In this respect, the effect of flooding on the seed bank is a key factor for the restoration and maintenance of natural vegetation (Bossuyt \& Honnay 2008), and understanding the effects of flooding on seed bank dynamics is vital to understanding the regeneration of floodplain plant communities (Bekker et al. 2000; Middleton 2003) and the seasonality of its vegetation (Bertiller 1992). Few studies on the recovery of degraded areas (Brock \& of Rogers 1998; Wetzel et al. 2001) and succession have focused on post-flooding recruitment from the soil seed bank, including response time and temporal variation in post-flood recruitment (Jutila 2001; Webb et al. 2006); none of which have taken place in the Pantanal wetland. We aimed to learn about post-flood regeneration, in order to better understand the dynamics of the Pantanal, perhaps the largest Neotropical wetland in the world. Towards this goal, we collected samples from the soil seed bank of the Pantanal floodplain, and conducted a greenhouse experiment to answer the following questions: 1) Does flooding positively influence seedling species richness and abundance? 2) Is there temporal variation in seedling recruitment, and if so, does it differ between flooded and non-flooded soil?

\section{Materials and methods}

\section{Study area}

The Pantanal wetland is located in the center of South America, and belongs to the upper Paraguay River Basin. The climate is warm and humid with rainy summers and dry winters, with a mean annual rainfall of around 1,100 $\mathrm{mm}$. It is considered a floristic mosaic (Adámoli 1982), with various phytophysiognomies (Pott et al. 2011) generated by the region's unique hydrology (Cunha \& Junk 2009; Fantin-Cruz et al. 2011).

The study area $\left(19^{\circ} 35^{\prime} 48.2^{\prime \prime} \mathrm{S}, 57^{\circ} 03^{\prime} 35.6^{\prime \prime} \mathrm{W}, 90 \mathrm{~m}\right.$ a. s. 1.) lies within the cattle ranch Fazenda São Miguel, in the Pantanal subregion of Miranda, with hydromorphic, sandy to clayey soils. It is a seasonally flooded savanna that is inundated by overflow from the Miranda River plus local rain. The landscape is composed mainly of natural grasslands in monodominant formations of park savanna of Tabebuia aurea (Silva Manso) Benth. \& Hook.f. ex S.Moore (locally called "paratudal") and of Byrsonima cydoniifolia A. Juss. ("canjiqueiral"), with forest patches (riparian forest and forest islets) and scattered shrubby, spiny thickets of Mimosa pigra L., Bauhinia bauhinioides (Mart.) J.F.Macbr. and vines.

Sampling was done in permanent plots established by the Program for Biodiversity Research (PPBio 2011), that were placed to include the various physiognomies, following the method RAPELD (RAP = Rapid Assessment, + PELD = LTER = Long Term Ecological Research). Five $250 \mathrm{~m}$-long transect lines, at the same altitude and separated by 1000 $\mathrm{m}$, were installed in a $5 \mathrm{~km}$ grid (for details see Costa \& Magnusson 2010). The area was grazed except when flooded.

\section{Collection of data and experimental design}

Data collection and the experiment were carried out in both the dry season (July 2012) and the rainy season (March 2013), in order to obtain the best estimate of species richness and composition. Each $250 \mathrm{~m}$-long transect was subdivided into $10 \mathrm{~m}$ segments, from which five transect segments were drawn for collecting four soil samples (20 samples/transect) of $20 \mathrm{~cm} \times 20 \mathrm{~cm} \times 3 \mathrm{~cm}, 2 \mathrm{~m}$ equidistant, and at $3 \mathrm{~m}$ from the transect line, according to the protocol for soil sampling of PPBio (2011).

To evaluate the soil seed bank and the effects of flooding, we employed the seedling emergence method (Thompson et al. 1997). Accordingly, after removing vegetative propagules, we spread the soil samples forming a ca. $2 \mathrm{~cm}$ layer over $3 \mathrm{~cm}$ of sterilized sand in perforated plastic trays of $30 \mathrm{~cm} \times 20 \mathrm{~cm}$ $x 6 \mathrm{~cm}$. The trays were randomly arranged in a screened (20\% shade) greenhouse covered with transparent plastic, without temperature conditioning. We adopted two treatments: 1 ) Post-flooded (PF), wherein 50 samples were submitted to 25 $\mathrm{cm}$ deep inundation for 30 days in polyethylene tanks, and 
thereafter they were removed and kept under irrigation; and 2) Non-flooded (NF), where another set of 50 samples were submitted only to irrigation by an automatic sprinkler twice a day to keep the soil moist but freely drained throughout the experiment. These treatments were designed to assure that any differences between treatments would not be caused by water deficiency in NF, but by flooding in PF. Emerged seedlings were identified, counted and removed at 15 day intervals for 120 days, for a total of eight samplings. Unidentifiable seedlings were transplanted to pots for subsequent identification.

Species were classified according to life form and life cycle (annual or perennial): annual herbs, perennial herbs, annual graminoids, perennial graminoids and woody (trees, shrubs and lianas). We included Poaceae, Cyperaceae and Typhaceae in graminoids (annual and perennial), and non-woody climbers in herbs (annual and perennial). The classification among life forms and life cycles was based on their representation and ecological importance in the natural grasslands of the Pantanal that were utilized for cattle grazing (e.g., Allem \& Valls 1987). Shrubby, arboreal and liana habits were grouped as part of the woody component because of the importance of many woody species as weeds in these grasslands (Junk \& Cunha 2012).

\section{Data analysis}

The 20 samples of each transect were drawn between treatments. Adding to 50 samples per treatment in each season (10 samples for each treatment $x 2$ treatments $x$ 5 transects $x 8$ periods $x 2$ seasons $=1600$ observations). Analyses were performed using the software R ( $R$ Core Team 2014). To test the effect of inundation on seedling recruitment and to describe the variation of this effect over time, we tested the differences between treatments in each of the eight periods separately. This analysis was made for the whole community and also for each plant group (life form). To test the effect of temporal variation on seedling recruitment and to describe the patterns of such variation in both treatments, we tested the variation in richness and abundance between periods in both treatments separately. Differences between all periods were tested using Tukey's test for multiple comparisons (Bretz et al. 2011). This analysis was made for the entire community. For both the effect of flooding and temporal variation we used Generalized Linear Mixed-effect models (GLMM) adjusted to maximum likelihood. The GLMM approach allows generalizations to be made regarding the distribution of the dependent variable, including a random component of the model (Zuur et al. 2009), making it convenient for our experiment since it has intrinsic random factors and a non-Gaussian distribution of the dependent variables. For richness data we used the Poisson distribution. In the models of abundance we detected over-dispersion (variance higher than the mean) when using the Poisson distribution, so we used the negative binomial distribution instead (Zuur et al. 2009). Although the samples along transects were distributed randomly, they still could have spatial dependence. Therefore, we added transects and seasons as random effects, so that the model would assume a different intercept value for each transect and season, thereby minimizing problems related to lack of independence. Furthermore, we added a random slope to the treatment effect, which allows the different responses of the treatment in each transect and season to be considered (Zuur et al. 2009; Winter 2013). For GLMM models we utilized the lme4 package v1.1-9 (Bates et al. 2015) and for temporal variation Tukey's test we utilized the multcomp package (Hothorn et al. 2008).

\section{Results}

In total, 33,181 seedlings from 124 species emerged in both treatments, with 15,810 seedlings of 119 species in NF (non-flooded) and 17,371 seedlings of 116 species in PF (post-flooded). We recorded 32 species of annual herbs, 37 perennial herbs, 20 perennial graminoids, nine annual graminoids and 23 woody species in both treatments. The most abundant life form was annual herbs $(16,475$ seedlings), followed by annual graminoids $(6,103)$, perennial graminoids $(5,405)$, perennial herbs $(2,141)$ and woody plants $(1,866)$. Four species can exhibit either annual or perennial behavior, and so were not considered in the analyses (Tab. S1 in supplementary material).

Eleven species occurred exclusively in NF: Mimosa weddelliana, Ludwigia sp., Stachytarpheta indica and Justicia laevilinguis. Sixteen species were exclusive to PF, among them Eleocharis minima, Nymphaea gardneriana, Mimosa pigra, Eleocharis acutangula, and Phyllanthus orbiculatus. However, these species that occurred in only one of the treatments had very low abundance (Tab. S1 in supplementary material). In NF the species with highest abundance were Euploca filiformis (1,993 seedlings), Richardia grandiflora $(1,879)$, Digitaria ciliaris $(1,837)$ and Cyperus haspan $(1,570)$. The species with highest abundance in PF were $R$. grandiflora $(3,641)$, E. procumbens $(2,374), D$. ciliaris $(1,615)$ and $C$. haspan $(1,198)$.

Regarding the effect of flooding in each period, and also the temporal variation of this effect, in general, the first periods (especially at 30 days) were affected by flooding, while in NF the last periods had higher values of abundance and richness (Fig. 1; Tab. S2-S7 in supplementary material). In the second period (30 days) perennial herbs showed the greatest change in richness $(z=4.67, p<0.001)$ and abundance $(z=6.4, p<0.001)$ for PF (Fig. 1A; Table S2 in supplementary material) from the first period followed by annual herbs (abundance: $z=3.44, p<0.001$; and richness: $\mathrm{z}=4.218, \mathrm{p}<0.001$ ), also at 30 days (Fig 1B; Tab 3). Significant flood influences also occurred with perennial graminoids, only in the first period (Fig. 1C; Tab S4 in supplementary material) and only in the second period 
Effects of flooding and its temporal variation on seedling recruitment

from the soil seed bank of a Neotropical floodplain
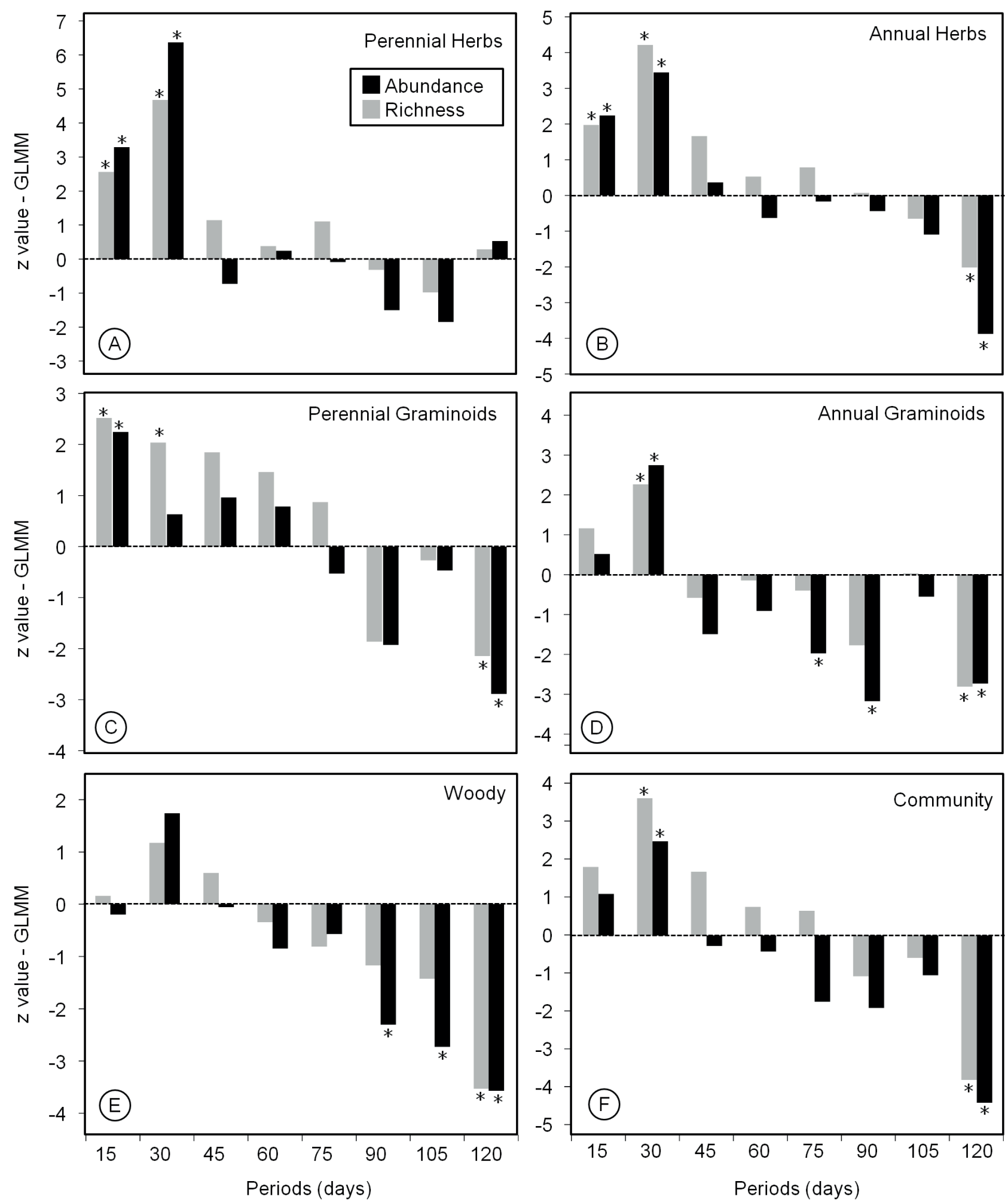

Figure 1. Differences in seedling recruitment between treatments for each life form (A, B, C, D, E) and for the entire plant community (F) in each period, from the soil seed bank of the Pantanal wetland. Each bar represents a z-value difference in richness (gray bars) and abundance (black bars) between treatments. Positive values indicate higher abundance and richness in the post-flooded (PF) treatment, and negative values, higher abundance and richness in the non-flooded (NF) treatment. *Significant difference between treatments $(\mathrm{p}<0.05)$. The figure refers to data of tables $S 2$ to $S 7$ in supplementary material. 
in annual graminoids (Fig. 1D; Tab S5 in supplementary material). Woody species were not influenced by flooding (Fig. 1E; Tab. S6 in supplementary material). When the entire community was analyzed, higher abundance and richness for $\mathrm{PF}$ in relation to NF occurred only in the second period (Fig. 1F; Table S7 in supplementary material).

Some annual species (herbs and graminoids), besides being the most abundant in total seedlings, were also notably more abundant in PF than in NF (Tab. S1 in supplementary material). Flooding notably increased the recruitment of $R$. grandiflora, E. procumbens, P. timoutoides and C. surinamensis, mostly in the initial PF periods (Fig. 2).

The effect of temporal variation was detected in both treatments (Fig. 3). In NF, richness tended to increase soon after the beginning of the experiment, with the highest mean value being achieved at 60 days (corresponding to the fourth period), and there was no significant reduction until the end of the experiment (Fig. 3A). Yet in PF the highest mean values occurred in the first periods, with reduction in the last periods (Fig. 3B). In NF the abundance followed a similar pattern as for richness (Fig. $3 \mathrm{C}$ ), while in $\mathrm{PF}$ the highest mean value of abundance occurred in the second period, differing significantly from all others. The abundance of recruited seedlings reduced progressively after 30 days, with the lowest value occurring in the last period (Fig. 3D), indicating a strong effect of PF in the first periods and declining recruitment from the seed bank thereafter.

\section{Discussion}

\section{Effect of flooding}

Seed bank assays of wetland soils placed in flooded and freely drained conditions have provided useful information elsewhere (e.g., Middleton 2003), as well as in the few studies in the Pantanal (Bao et al. 2014; Oliveira et al. 2015). Our results are novel in that they indicate that flooding provides favorable conditions for an increase in species richness and abundance in seedling recruitment soon after water had receded. These findings support the general conception that seasonal flooding is essential for the Pantanal (Alho \& Sabino 2012; Pott \& Silva 2015). The fact that the highest seedling richness and abundance in PF (post-flooded)
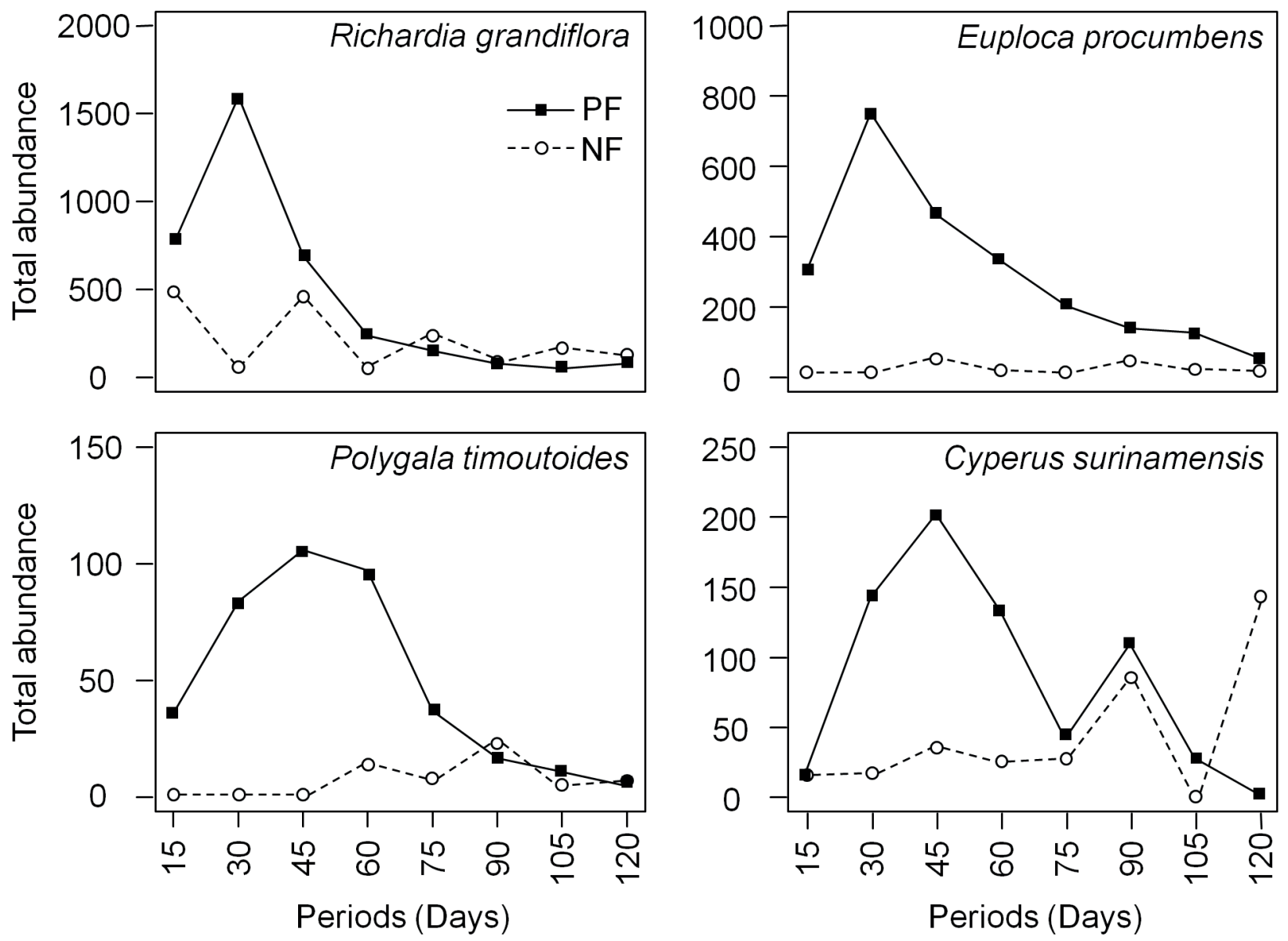

Figure 2. Total abundance of seedlings of the main annual species recruited from the seed bank in the non-flooded (NF) and postflooded (PF) treatments, from soil sampled in the Pantanal wetland. 

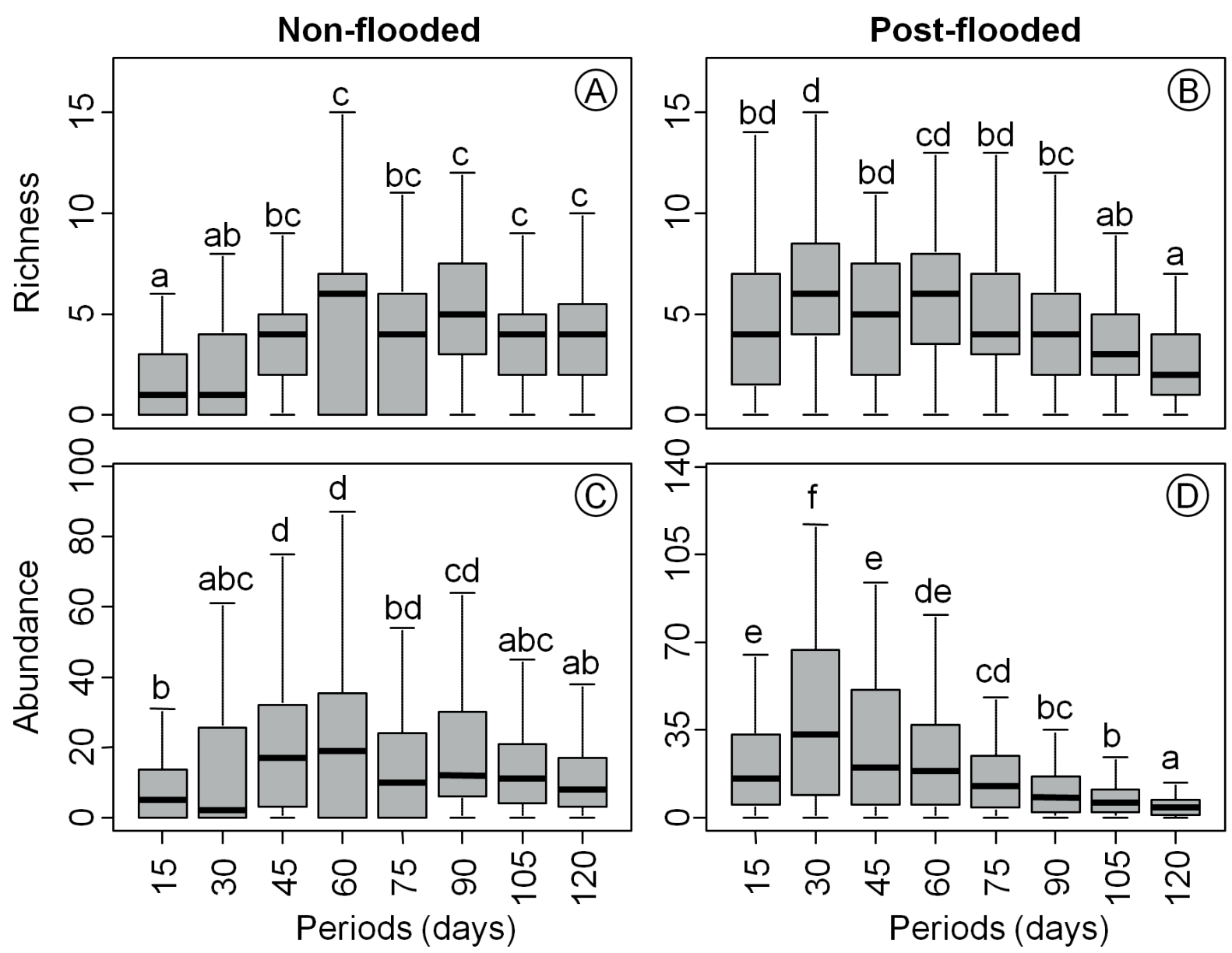

Figure 3. Differences in recruitment of seedlings from the soil seed bank in the Pantanal wetland between non-flooded (NF) and post-flooded ( $\mathrm{PF}$ ) treatments. Letters indicated significant differences between periods, as calculated by Tukey's post-hoc test ( $\mathrm{p}<0.05$ ).

were in the early periods, and the highest values in NF (non-flooded) were in the later periods, suggests that flooding in the beginning of the experiment caused high recruitment, which decreased progressively the number of non-dormant seeds stored in the soil towards the final periods. Overall, maintenance of humid soil in NF during the entire experiment may have contributed to this result, since humid soil over a long period can be fundamental for species recruitment (Brock \& Rogers 1998; Capon 2007).

Among all life forms, herbs (annual and perennial) had the highest richness and abundance in PF, reflecting a tendency for these species to respond positively to flooding (Capon \& Brock 2006; Capon 2007), and highlights the importance of the seed bank of such species for post-flood recovery of vegetation (Middleton 2003; Hölzel \& Otte 2004; Lu et al. 2010). In addition to herbs, the graminoid species also represented an important component of the vegetation. Their regeneration from seeds can also increase as a result of flooding, plus they can regrow from rhizomes, a common trait in wetland Cyperaceae and Poaceae. Thus, the higher richness and abundance for herbs and graminoids (annual and perennial) in PF indicates that these species depend on flooding for their greatest seedling recruitment. In our study we can identify some particular annual species (herbs and graminoids) with the highest abundance of seedlings emerged in PF, indicating that they are the main dependents on flooding for recruitment. These include, in particular, R. grandiflora, E. procumbens, P. timoutoides and C. surinamensis.

Since annual species have short life cycles, extreme events make them dependent on seeds accumulated in the soil to persist in a community (Milberg \& Hansson 1993). However, some annual species of wetlands under predictable flooding events produce transitory seed banks, generally during a dispersal season combined with adequate conditions for germination (Saatkamp et al. 2014). In the southern Pantanal, floods are generally delayed relative to the rainy season (Hamilton et al. 1996), so the soil stays wet for a greater part of the year. Thus, both strategies, persistent and/or transitory seed banks, may be advantageous to annual species, since there would be suitable conditions for germination throughout most of the year. 
Another factor that can contribute to the greater success of annuals is the lower rates of germination and survival of perennial species (Parker \& Leck 1985). Thus, in the PF treatment, the higher richness of annual species (either herbs or graminoids), along with their higher abundance of seedlings (16,475 herbs and 6,103 graminoids), compared with the perennials (2,141 herbs and 5,405 graminoids), indicates that annuals are largely responsible for the renewal of plant cover soon after a flood, and can therefore contribute significantly to seasonal changes in composition of the established plant community (Hopfensperger et al. 2009).

Considering the above interpretation, the absence of flooding would drastically reduce seedling recruitment of some species, such as $R$. grandiflora, $P$. timoutoides, E. procumbens, and $C$. surinamensis, and others with recruitment expressively increased by flooding (Fig. 2), thereby modifying the dynamics of the system. Although some species in floodplains have persistent seeds with the strategy of a residual bank (bet hedging strategy; Venable 1989), seeds that do not germinate due to lack of flooding could undergo a much longer dry period, which could hinder recruitment even more due to desiccation, physiological death, predation, burial, etc. (Baker 1989). Furthermore, under long periods without flooding, species with transitory seed banks could become locally extinct (Thompson \& Grime 1979; Saatkamp et al. 2014).

In contrast to herbs and graminoids, our results for the richness and abundance of woody species indicate that flooding is not a determinant factor for their recruitment. In fact, their establishment can be suppressed by flooding during seed germination or seedling growth (Kozlowski 1984; 1997). Hence, woody species depend on a lapse in seasonal flooding in order to colonize floodable grasslands (Wetzel et al. 2001). Considering that long periods of drought without inundation (Hamilton et al. 1996), do not occur in this southern subregion of the Pantanal, except in very dry years, these woody plants are adapted to a habitat that is humid throughout most of the year. Hence, if the frequency of flooding decreases, and water deficit does not occur, woody species tend to encroach (Junk \& Cunha 2012). So, humid soil for an extended time and the absence of flooding can be essential abiotic conditions for the successful establishment of woody species. However, woody species can be poorly represented in wetland seed banks (Middleton 2003).

The concern about woody plants in the Pantanal is due to the importance of grassland vs. woodland savanna dynamics for purposes of cattle ranching and conservation (Pott \& Silva 2015). Among the woody species we recorded, only Microstachys hispida is considered to be a weed of floodable natural grasslands in the Pantanal (Allem \& Valls 1987), although it is a native plant. This species can be considered an indicator of degraded floodable grassland, because it spreads in dry years when overgrazing or fire occurs (Pott
1982, Pott \& Pott 1994). Other woody species that are considered weeds of floodable grassland, such as Byrsonima cydoniifolia, Licania parvifolia and Sphinctanthus microphyllus (Allem \& Valls 1987), were present in the vegetation, but did not emerge from the seed bank. They invade floodable grasslands of the Pantanal in years without flooding, or when flooding is not intense enough to inhibit their initial stages (Junk \& Cunha 2012). Nevertheless, some woody species are able to establish under flood conditions due to their possessing morphological and physiological traits that help them withstand flooding to a certain depth, even during the seedling phase (e.g., Vochysia divergens, Cunha \& Junk 2004). When flooding does not reach some areas or when it is not sufficient to suppress woody vegetation, such shrubs and trees tend to encroach into grasslands, while the establishment of herbs can be restricted, resulting in modified open landscapes, which has caused drastic changes to the physiognomy of the Pantanal (Cunha \& Junk 2001; Junk \& Cunha 2012). Hence, flooding functions as a filter of intolerant woody species, mainly during the phases of their initial growth (Junk \& Cunha 2012), which results in species richness and composition reflecting the predominance of grasslands and meadows in flood prone areas in the Pantanal (Pott \& Silva 2015).

\section{Temporal variation}

Differences in recruitment among periods in both treatments and, moreover, differences in the pattern of temporal variation between treatments, with higher recruitment at the beginning of the experiment for $\mathrm{PF}$, shows that not only can flooding be essential for the quantity of recruited seedlings, but it can also act as a trigger for an abrupt increase in recruitment. This is supported by the fact that, of the entire plant community, $75.5 \%$ of the seedlings in PF emerged in the first 60 days of the experiment, compared with $52.3 \%$ in NF over the same period. Some annual species had well defined peaks, with expressively higher abundance in the beginning of the experiment in PF compared with NF (Fig. 2). This result indicates that annuals are the main cause of the higher initial recruitment in PF.

In general, annual species, both graminoids and herbs, have high reproductive investment, producing large quantities of seeds (Baldwin \& Derico 1999). Many of them can sustain a seed bank with each reproductive event, thereby maintaining a stable abundance (Capon 2007). In addition to the strategy of a residual seed bank, another factor that can contribute to the success of these species, as already been mentioned, is the delay in flooding in relation to the rainy season in this southern subregion of the Pantanal (Hamilton et al. 1996), which provides favorable conditions for these species to germinate during most of the year. Species such as Richardia grandiflora, due to their fast post-flood emergence (Fig. 2), may be considered initial 
colonizers (pioneers) (Pott \& Pott 1994). Furthermore, $R$. grandiflora may be considered a weed, and reach up to $100 \%$ of soil cover (Allem \& Valls 1987) and hinder germination and emergence of other species (FLEPPC 2015).

Nonetheless, besides the aggressive behavior of some annual species, the fast and abundant recruitment of annuals enhances recolonization of gaps left by flood events, and can offer resources to other initial colonizers. Upon completion of their reproductive cycle, annual plants die, thereby giving room to other species (Reis et al. 2010). Therefore, the fast emergence of annual species can favor the entire postflood succession (Lortie \& Turkington 2008). In conclusion, flooding can be seen as structuring phenomenon for floodplain vegetation, as it speeds up seasonal recolonization of gaps by increasing and accelerating the recruitment of herbs and graminoids, particularly annuals.

\section{Acknowledgements}

To Brazilian agency CAPES for scholarship to E. B. Souza and Visiting Professor grant to A. Pott, who also has a CNPq research grant; Instituto Nacional de Ciência e Tecnologia em Áreas Úmidas (INAU) for financial support; Claudia Zukeran Kanda and Rafael Arruda for suggestions on the manuscript; Rosa Helena da Silva helped with fieldwork; Francielli Bao and Vali J. Pott assisted in seedling identification; Erik Wild for English revision; Fazenda São Miguel for access to the study area.

\section{References}

Adámoli J. 1982. O Pantanal e suas relações fitogeográficas com os Cerrados: discussão sobre o conceito de "Complexo do Pantanal". Annals of $32^{\circ}$ Congresso Nacional de Botânica. Teresina, Sociedade Botânica do Brasil. p. 109-119.

Alho C, Sabino J. 2012. Seasonal Pantanal flood pulse: implications for biodiversity. Oecologia Australis 16: 958-978.

Allem AC, Valls JFM. 1987. Recursos forrageiros nativos do Pantanal Mato-Grossense. Brasília, Embrapa-Cenargen.

Baker HG. 1989. Some aspects of the natural history of seed banks. In: Leck MA, Parker VT, Simpson RL. (eds.). Ecology of soil seed banks. London, Academic Press. p. 5-19.

Baldwin AH, Derico E. 1999. The seed bank of a restored tidal freshwater marsh in Washington, DC. Urban Ecosystems 3: 5-20.

Bao F, Pott A, Ferreira FA, Arruda R. 2014. Soil seed bank of floodable native and cultivated grassland in the Pantanal wetland: effects of flood gradient, season and species invasion. Brazilian Journal of Botany 37: 239-250.

Bates D, Maechler M, Bolker B, Walker S. 2015. Fitting linear mixed-effects models using lme4. Journal of Statistical Software 67: 1-48.

Bekker RM, Verweij GL, Bakker JP, Fresco LFM. 2000. Soil seed bank dynamics in hayfield succession. Journal of Ecology 88: 594-607.

Bertiller MB. 1992. Seasonal variation in the seed bank of a Patagonian grassland in relation to grazing and topography. Journal of Vegetation Science 3: 47-54.

Bossuyt B, Honnay O. 2008. Can the seed bank be used for ecological restoration? An overview of seed bank characteristics in European communities. Journal of Vegetation Science 19: 875-884.

Bretz F, Hothorn T, Westfall P. 2011. Multiple comparisons using R. London, Chapman \& Hall/CRC.
Brock MA. 2011. Persistence of seed banks in Australian temporary wetlands. Freshwater Biology 56: 1312-1327.

Brock MA, Rogers KH. 1998. The regeneration potential of the seed bank of an ephemeral floodplain in South Africa. Aquatic Botany 61: 123-135.

Capon SJ. 2007. Effects of flooding on seedling emergence from the soil seed bank of a large desert floodplain. Wetlands 27: 904-914.

Capon SJ, Brock MA. 2006. Flooding, soil seed bank dynamics and vegetation resilience of a hydrologically variable desert floodplain. Freshwater Biology 51: 206-223.

Costa FRC, Magnusson WE. 2010. The need for large-scale, integrated studies of biodiversity - the experience of the Program for Biodiversity Research in Brazilian Amazonia. Natureza \& Conservação 8: 3-12.

Cunha C, Junk WJ. 2001. Distribution of Woody Plant Communities along the Flood Gradient in the Pantanal of Poconé, Mato Grosso, Brazil. International Journal of Ecological Environment Science 27: 63-70.

Cunha C, Junk WJ. 2004. Year-to-year changes in water level drive the invasion of Vochysia divergens in Pantanal grasslands. Applied Vegetation Science 7: 103-110.

Cunha C, Junk WJ. 2009. Landscape units of the Pantanal: structure, function, and human use. In: Silva CJ, Cunha C, Wantzen KM. (eds.) The Pantanal: Ecology, biodiversity and sustainable management of a large Neotropical seasonal wetland. Sofia, Pensoft. p. 127-141.

Fantin-Cruz I, Pedrollo O, Castro NMR, Girard P, Zeilhofer P, Hamilton SK. 2011. Historical reconstruction of floodplain inundation in the Pantanal (Brazil) using neural networks. Journal of Hydrology 399: 376-384.

FLEPPC - Florida Exotic Pest Plant Council. 2015. List of Invasive Plant Species. http://www.fleppc.org/list/list.htm. 30 May 2016.

Hamilton SK, Sippel SJ, Melack JM. 1996. Inundation patterns in the Pantanal wetland of South America determined from passive microwave remote sensing. Archiv fur Hydrobiologie 137: 1- 23.

Hölzel N, Otte A. 2004. Inter-annual variation in the soil seed bank of flood-meadows over two years with different flooding patterns. Plant Ecology 174: 279-291.

Hopfensperger KN, Engelhardt KAM, Lookingbill TR. 2009. Vegetation and seed bank dynamics in a tidal freshwater marsh. Journal of Vegetation Science 20: 767-778.

Hothorn T, Bretz F, Westfall P. 2008. Simultaneous Inference in General Parametric Models. Biometrical Journal 50: 346-363.

Junk WJ, Cunha C. 2012. Pasture clearing from invasive woody plants in the Pantanal: a tool for sustainable management or environmental destruction? Wetlands Ecology and Management 20: 111-122.

Junk WJ, Bayley PB, Sparks RE, 1989. The flood pulse concept in river floodplain systems. Canadian Journal Fishing Aquatic Science 106: 110-127.

Jutila HM. 2001. Effect of flooding and draw-down disturbance on germination from a seashore meadow seed bank. Journal of Vegetation Science 12: 729-738.

Kozlowski TT. 1984. Flooding and plant growth. Orlando, Academic Press, INC.

Kozlowski TT. 1997. Responses of woody plants to flooding and salinity. Tree Physiology Monograph 1: 1-29.

Leck MA. 1989. Wetland seed bank. In: Leck MA, Parker VT, Simpson RL. (eds.) Ecology of soil seed banks. London, Academic Press. p. 282-305.

Lortie CJ, Turkington R. 2008. Species-specific positive effects in an annual plant community. Oikos 117: 1511-1521.

Lu ZJ, Li LF, Jiang MX, Huang HD, Bao DC. 2010. Can the soil seed bank contribute to revegetation of the drawdown zone in the Three Gorges Reservoir Region? Plant Ecology 209: 153-165.

Middleton BA. 2002. Flood Pulsing in Wetlands: Restoring the Natural Hydrological Balance. New York, John Wiley and Sons.

Middleton BA. 2003. Soil seed banks and the potential restoration of forested wetlands after farming. Journal Applied Ecology 40: 10251034

Milberg P, Hansson ML. 1993. Soil seed bank and species turnover in a limestone grassland. Journal of Vegetation Science 4: 35-42.

Oliveira PC, Torezan JMD, Cunha C. 2015. Effects of on the spatial distribution of soil seed and spore banks of native grasslands of the Pantanal wetland. Acta Botanica Brasilica 29: 400-407. 
Pagotto M, Silveira RML, Cunha C, Fantin-Cruz I. 2011. Distribution of herbaceous species in the soil seed bank of a flood seasonality area, northern Pantanal, Brazil. International Review of Hydrobiology 96: 149-163.

Parker VT, Leck MA. 1985. Relationship of seed banks to plant distribution patterns in a freshwater tidal wetland. American Journal of Botany 72: 161-174.

Peterson JE, Baldwin AH. 2004. Seedling emergence from seed banks of tidal freshwater wetlands: response to inundation and sedimentation. Aquatic Botany 78: 243-254.

Pott, A. 1982. Pastagens das sub-regiões dos Paiaguás e da Nhecolândia do Pantanal Mato-Grossense. Circular Técnica n 10. Corumbá, EmbrapaCPAP.

Pott A, Oliveira AKM, Damasceno-Junior GA, Silva JSV. 2011. Plant diversity of the Pantanal wetland. Brazilian Journal of Biology 71: 265-273.

Pott A, Pott VJ. 1994. Plantas do Pantanal. Brasília, Embrapa.

Pott A, Silva JSV. 2015. Terrestrial and aquatic vegetation diversity of the Pantanal Wetland. In: Bergier I, Assine, ML. (eds.) Dynamics of the Pantanal Wetland in South America. Cham, Springer International Publishing Switzerland. p. 111- 151.

PPBio - Programa de Pesquisa em Biodiversicade. 2011. Protocolo de coleta de solos. http://ppbio.inpa.gov.br/manuais. 20 May 2012.

R Core Team. 2014. R: A language and environment for statistical computing. R Foundation for Statistical Computing, Vienna, Austria. URL: https://www.r-project.org/. 2 Apr. 2014.

Reis A, Bechara FC, Tres DR. 2010. Nucleation in tropical ecological restoration. Scientia Agricola 67: 244-250.

Saatkamp A, Poschlod P, Venable DL. 2014. The functional role of soil seed banks in natural communities. In: Gallagher RS. (ed.) Seeds: the ecology of regeneration in plant communities. Ed. 3. Wallingford, CABI. p. 263- 295

Thompson K, Grime JP. 1979. Seasonal-variation in the seed banks of herbaceous species in 10 contrasting habitats. Journal of Ecology 67: 893-921.

Thompson K, Bakker J, Bekker R. 1997. The soil seed banks of North West Europe: methodology, density and longevity. Cambridge, Cambridge University Press.

Valk AG, 1981. Succession in wetlands: a gleasonian approach. Ecology 62: 688-696.

Valk AG. 2005. Water-level fluctuations in North American prairie wetlands. Hydrobiologia 539: 171-188.

Valk AG, Davis CB, 1978. The role of seed banks in the vegetation dynamics of prairie glacial marshes. Ecology, 59: 322-335.

Venable D. 1989. Modeling the evolutionary ecology of seed banks. In: Leck MA, Parker VT, Simpson RL. (eds.) Ecology of soil seed banks. San Diego, Academic Press. p. 67-87.

Webb M, Reid M, Capon S, Thoms M, Rayburg S, James C. 2006. Are flood plain-wetland plant communities determined by seed bank composition or inundation periods? Sediment Dynamics and the Hydromorphology of Fluvial Systems (Proceedings of a symposium held in Dundee, UK, July 2006). Dundee, IAHS Publ. 306: 241-248.

Wetzel PR, Valk AG, Toth LA. 2001. Restoration of wetland vegetation on the Kissimmee River Floodplain: Potential role of seed banks. Wetlands 21: 189-198.

Winter B. 2013. Linear models and linear mixed effects models in $\mathrm{R}$ with linguistic applications. arXiv:1308.5499. [http://arxiv.org/ pdf/1308.5499.pdf]. 13 May 2016.

Zuur AF, Ieno EN, Walker NJ, Saveliev AA, Smith G. 2009. Mixed effects models and extensions in ecology with R. New York, Springer. 